\title{
Drynaria fortunei-derived total flavonoid fraction and isolated compounds exert oestrogen-like protective effects in bone
}

\author{
Ka-Chun Wong ${ }^{1}$, Wai-Yin Pang ${ }^{1}$, Xin-Lun Wang ${ }^{2,3}$, Sao-Keng Mok ${ }^{1}$, Wan-Ping Lai ${ }^{1}$, Hung-Kay Chow ${ }^{4}$, \\ Ping-Chung Leung ${ }^{5}$, Xin-Sheng Yao $^{3,6 *}$ and Man-Sau Wong ${ }^{1,7 *}$ \\ ${ }^{1}$ Department of Applied Biology and Chemical Technology, The Hong Kong Polytechnic University, Hung Hom, Kowloon, \\ Hong Kong, People's Republic of China \\ ${ }^{2}$ Translational Medicine Research and Development Center, Institutes of Advanced Technology, Chinese Academy of \\ Sciences, Shenzhen, People's Republic of China \\ ${ }^{3}$ College of Traditional Chinese Materia Medica, Shenyang Pharmaceutical University, Shenyang 110016, People's Republic \\ of China \\ ${ }^{4}$ Interdisciplinary Division of Biomedical Engineering, The Hong Kong Polytechnic University, Hung Hom, Kowloon, Hong \\ Kong, People's Republic of China \\ ${ }^{5}$ Department of Orthopaedics and Traumatology, The Chinese University of Hong Kong, Hong Kong, People's Republic of \\ China \\ ${ }^{6}$ Institute of Traditional Chinese Medicine and Natural Products, College of Pharmacy, Jinan University, Guangzhou \\ 510632, People's Republic of China \\ ${ }^{7}$ State Key Laboratory of Chinese Medicine and Molecular Pharmacology (Incubation), Shenzhen, People's Republic of China
}

(Submitted 29 June 2012 - Final revision received 2 November 2012 - Accepted 2 November 2012 - First published online 10 January 2013)

\section{Abstract}

Drynaria fortunei (Kunze) J. Sm. (DF), a Chinese herb commonly used for the treatment of bone fracture, was previously shown to exert anabolic effects on bone. However, its active ingredients as well as the mechanisms of action are far from clear. The present study aimed to characterise the bone anabolic effects of DF flavonoid fraction (DFTF) in ovariectomised (OVX) mice and to determine if DFTF and its isolated compounds exert oestrogen-like effects in rat osteoblast-like UMR-106 cells. Young OVX C57/BL6J mice were treated orally with DFTF ( $(0.087,0.173$ or $0.346 \mathrm{mg} / \mathrm{g}$ per d), $17 \beta$-oestradiol $(2 \mu \mathrm{g} / \mathrm{g}$ per d) or its vehicle for 6 weeks. Serum and urine samples were collected for biochemical marker analysis. Bones were collected for computed tomography analysis. UMR-106 cells were treated with DFTF and isolated compounds naringin, (2S)-5,7, $3^{\prime}, 5^{\prime}$-tetrahydroxy-flavonone 7-O-neohesperidoside (compound 1) and 5,7-dihydroxychromone 7-O-neohesperidoside (compound 2). DFTF exerted dose-dependent effects in improving bone mineral densities as well as bone strength at the femur, tibia and lumbar spine L1 in OVX mice. DFTF and the three isolated compounds stimulated osteoblastic cell proliferation and alkaline phosphatase activities in a dose-dependent manner. In addition, they stimulated the ratio of osteoprotegrin and receptor-activator NF-KB ligand mRNA expression, suggesting their involvement in inhibiting osteoclastogenesis. These stimulatory effects on osteoblastic functions were abolished in the presence of oestrogen receptor (ER) antagonist, ICI 182780. The present results suggested that DFTF is effective in protecting against OVX-induced bone loss in mice, and its actions in regulating osteoblastic activities appear to be mediated by ER.

Key words: Drynaria fortunei: Total flavonoids: Naringin: Bone properties: Osteoblasts: Oestrogen receptors

With the increase in ageing population, osteoporosis has become a major public health problem worldwide that requires the development of a novel approach for its prevention and treatment ${ }^{(1)}$. In particular, postmenopausal women are of high risk of developing osteoporosis due to the significant alterations in bone metabolism associated with oestrogen deficiency. The rapid bone loss and the increase in bone fragility during menopause have led to the increase in incidence rate of fractures of vertebrae in the spine, hips and wrists among postmenopausal women ${ }^{(2,3)}$

Abbreviations: ALP, alkaline phosphatase; BMD, bone mineral density; C, control group; compound 1, (2S)-5,7,3',5'-tetrahydroxy-flavonone 7-O-neohesperidoside; compound 2, 5,7-dihydroxychromone 7-O-neohesperidoside; Cr, creatinine; DF, Drynaria fortunei; DFTF, Drynaria fortunei total flavonoids; Dpd, deoxy-pyridinoline; $\mathrm{E}_{2}, 17 \beta$-oestradiol; ER, oestrogen receptor; MTS, 3-(4,5-dimethylthiazol-2-yl)-5-(3-carboxymethoxy phenyl)2-(4-sulphophenyl)-2H tetrazolium; OPG, osteoprotegerin; OVX, ovariectomised; RANKL, receptor activator of NF-kB ligand; SSI, stress-strain index.

*Corresponding authors: Dr M.-S. Wong, fax +852 23649932, email bcmswong@polyu.edu.hk; X.-S. Yao, email tyaoxs@jun.edu.cn 
Hormone replacement therapy was a major regimen for the management of postmenopausal osteoporosis in the past. However, with the report of the increased risk in developing stroke and breast cancer associated with its use $\mathrm{e}^{(4)}$, there is a strong demand to develop affordable alternative approaches with minimal side effects for the management of postmenopausal osteoporosis. This is particularly important for ageing populations in developing countries, as the majority of patients could not afford long-term use of high-cost medications.

Dietary sources of phyto-oestrogens (plant-derived compounds that have oestrogenic properties) are increasingly popular due to their potential beneficial effects on human health $^{(5)}$. Recent reports indicated that phyto-oestrogens can attenuate bone loss associated with oestrogen deficiency in both animal and human studies ${ }^{(1,3)}$. Phyto-oestrogens with demonstrated bone-protective effects include soya isoflavones $^{(6,7)}$, lignans $^{(8)}$ and flavonoids ${ }^{(9,10)}$. Experimental studies $^{(7)}$ showed that a diet containing soya extract (Novasoy), but not purified genistein, significantly preserved trabecular bone mass, bone volume and trabecular bone separation in the proximal tibial metaphysis of OVX mice. In addition, high dietary phyto-oestrogen intake was found to be associated with higher bone mineral density (BMD) in postmenopausal but not premenopausal women, suggesting that the positive effects of phyto-oestrogen on bone are influenced by the hormonal status of the individuals ${ }^{(11)}$.

Furthermore, recent studies indicated that Chinese herbs that are traditionally used for the management of bone diseases exert oestrogen-like activities on bone $e^{(12-14)}$ and might serve as a potential source of phyto-oestrogens for the management of postmenopausal osteoporosis.

The dried rhizome of Drynaria fortunei (Kunze) J. Smith (Polypodiaceae) (DF) is a Chinese herb traditionally used for the treatment of bone fractures or related diseases ${ }^{(15)}$. Its Chinese name is 'Gu Sui Bu', which means bone fractures healer. Accumulating evidence demonstrated the bone-protective effects of DF in both cell cultures and animal studies ${ }^{(16-24)}$. Its crude extract has been shown to promote osteoblast differentiation and mineralisation in preosteoblastic MC3T3-E1 cells ${ }^{(17,18,23)}$, increase the proliferation of human osteoprecursor 1 cells ${ }^{(19)}$ as well as inhibit in vitro bone resorption in mouse osteoclasts ${ }^{(25)}$. In addition, administration of DF crude extract $(6.6 \mathrm{mg} / \mathrm{d})$ to 8 -week-old BALB/c male mice for 5 weeks increased bone volume/tissue volume by $6.5 \%$, trabecular number by $10 \%$ and decreased trabecular separation by $9.7 \%$. DF crude extract was also shown to induce bone formation on the margin of defects created in the parietal bone of New Zealand white rabbits ${ }^{(21)}$. Furthermore, the total flavonoid fraction of DF (DFTF) was shown to significantly restore ovariectomy (OVX)-induced bone loss in rats ${ }^{(22)}$, while different DF fractions were found to increase BMD of the femur head in OVX mice ${ }^{(26)}$.

Phytochemical analysis of DF extract indicated that flavonoids ${ }^{(26,27-29)}$ and phenylpropanoids ${ }^{(28,30)}$ were the active ingredients that account for its osteoprotective activities. One of the highly abundant flavanoid compounds identified in $\mathrm{DF}$ is naringin, which is also the major bone-protective ingredient found in citrus fruits ${ }^{(31)}$. Naringin was shown to improve bone quality in retinoic acid-induced osteoporosis rats ${ }^{(32)}$ and orchidectomised rat ${ }^{(33)}$ models. Moreover, the direct effects of naringin on proliferation and differentiation of bone cells were demonstrated in murine osteoblast-like MC3T3-E1 cells ${ }^{(34,35)}$ and rat osteoblast-like UMR-106 cells ${ }^{(36,37)}$. Our recent study also reported that naringin was effective in protecting against OVX-induced bone loss in mice and that the stimulatory effects of naringin on osteoblastic functions in UMR-106 cells were oestrogen receptor (ER) dependent ${ }^{(36)}$, suggesting that it might act as a phyto-oestrogen in bone tissue.

The present study aimed to systematically characterise the dose-dependent effects of DFTF on bone properties in OVX mice as well as the oestrogenic effects of DFTF and its isolated compounds on osteoblastic functions in UMR-106 cells. It is hoped that the studies would provide evidence to support the use of $D$. fortunei as an alternative for the prevention and treatment of postmenopausal osteoporosis.

\section{Experimental methods}

\section{Materials}

All reagents for cell culture, RT-PCR and plasmid transient transfection kit were purchased from Life Technologies, Inc., unless otherwise indicated. $17 \beta$-Oestradiol $\left(E_{2}\right)$ was purchased from Sigma-Aldrich. The anti-oestrogen, ICI 182780 , was purchased from Tocris Cookson Limited. Primers were obtained from Tech Dragon Limited. Commercial diets were purchased from Teklad.

\section{Preparation of rhizoma Drynaria total flavonoid extract and characterisation of single compounds}

Rhizomes of $D$. fortunei were collected in Guizhou province, China, in 2005, and were identified by Professor Zhou Rong-Han (Chinese Pharmaceutical University, Nanjing, Jiansu, China) and extracted as described previously ${ }^{(26)}$. In brief, rhizomes of DF were cut and extracted with $60 \%$ ethanol to yield $60 \%$ ethanol extract. The extract was further separated by a D-101 macroporous resin column $(\Phi 25 \times 150 \mathrm{~cm})$ with gradient elution of water (DFA), 30\% (DFB), 50\% (DFC) and $95 \%$ (DFD) ethanol to yield four different fractions. DFB, DFC and DFD were positive to $\mathrm{HCl}-\mathrm{Mg}$ powder reaction, which was identified as the flavonoids fraction of DF. They were combined to yield DFTF. Single compounds were isolated through HPLC on a Shimadzu $C_{18}$ column $(\Phi 250 \times 4.6 \mathrm{~cm})$ in an Agilent series 1100 HPLC (Agilent Technologies, Inc.) in the DFB fraction. The peaks of the HPLC chromatogram from DFB were identified as previously described ${ }^{(26)}$. The structure of the three most abundant isolated compounds in DFB are shown in Fig. 1, which are naringin, (2S)-5,7,3 $3^{\prime}, 5^{\prime}$-tetrahydroxy-flavonone 7-O-neohesperidoside (compound 1) and 5,7-dihydroxychromone 7-O-neohesperidoside (compound 2), with a yield of $0.045,0.134$ and $0.022 \%$. The chemical name of compounds 1 and 2 are $(S)-7-(((2 S, 3 R, 4 S, 5 S, 6 R)-4,5$-dihydroxy-6-(hydroxymethyl)-3-(( $(2 S, 3 R, 4 R, 5 R, 6 S)-3,4,5$-trihydroxy6-methyltetrahydro-2H-pyran-2-yl)oxy)tetrahydro-2H-pyran2-yl)oxy)-2-(3,5-dihydroxyphenyl)-5-hydroxychroman-4-one 
<smiles>N#Cc1cc(O)c2c(c1)O[C@H](c1ccc(O)cc1)CC2=O</smiles>

$\mathrm{R}=$ neohesperidosyl

Compound $1:(2 \mathrm{R})$-naringen<smiles>[R6]c1cc(O)c2c(c1)O[C@H](c1cc(O)cc(O)c1)CC2=O</smiles>

$\mathrm{R}=$ neohesperidosyl

Compound 2<smiles>[R6]c1cc(O)c2c(=O)ccoc2c1</smiles>

the course of the studies, as previously described ${ }^{(36)}$. The care and treatment protocol were approved by the Animal Ethics Committee of the Hong Kong Polytechnic University.

At $1 \mathrm{~d}$ before killing, the mice were placed in metabolism cages. Their urine sample was collected, centrifuged and stored at $-20^{\circ} \mathrm{C}$ until use. At the end of treatment, the mice were anaesthetised with $10 \%$ ketamine $(75 \mathrm{mg} / \mathrm{kg}$, \#013004; Alfamedic Limited). Blood samples were taken from the inferior vena cava, followed by the collection of uteri and bone specimens (femur, tibia and lumbar spine). The serum samples of the mice were stored at $-80^{\circ} \mathrm{C}$ and the left femur, tibia and lumbar spine were stored at $-20^{\circ} \mathrm{C}$ until analysis.

\section{Biochemical assays of serum and urine samples}

$\mathrm{Ca}$ and $\mathrm{P}$ concentrations of the serum and urine samples were studied by the $O$-cresolphthalein complexon colour development method and p-methylaminophenol method, respectively. Both biomarkers were measured by commercial kits (Wako Pure Chemical Industries Limited). The urinary excretion of deoxy-pyridinoline (Dpd), a collagen degradation product that reflects bone resorption rate, was measured using a Metra ${ }^{\circledR}$ DPD EIA kit (Quidel) with a microplate reader. Urinary creatinine (Cr) was used as an internal control and was assessed with the Jaffe method using a commercial kit (Wako Pure Chemical Industries Limited). Urinary Ca, P and Dpd levels were expressed as its excretion per unit of $\mathrm{Cr}$ (Ca/Cr, P/Cr and Dpd/Cr).

\section{Assessment of bone properties by peripheral quantitative computed tomography}

and 7-(((2S,3R,4S,5S,6R)-4,5-dihydroxy-6-(hydroxymethyl)-3-(((2S, $3 R, 4 R, 5 R, 6 S)-3,4,5$-trihydroxy-6-methyltetrahydro-2H-pyran-2yl)oxy) tetrahydro-2H-pyran-2-yl)oxy)-5-hydroxy-4H-chromen-4-one. Three isolated compounds were characterised on the basis of comprehensive analyses of their mono- and bi-dimensional NMR spectra. Naringin ${ }^{(38)}$, compound $1^{(26)}$ and compound $2^{(39)}$ were identified by comparing their spectral data with previously reported data.

\section{Animal care and diet}

A total of sixty 1-month-old female C57/BL6J mice (obtained from the Chinese University of Hong Kong) were housed in environmentally controlled central animal facilities. The mice were either sham-operated or OVX at the age of 1 month for simulating an oestrogen-deficient environment. After a 2-week recovery period, the mice were randomly divided into six groups: sham vehicle ( $2 \%$ ethanol); OVX vehicle; $\mathrm{OVX} \mathrm{E}_{2}$ $(2 \mu \mathrm{g} / \mathrm{g}$ per $\mathrm{d}$ ) and three groups of OVX DFTF extract (low dose: 0.087; medium dose: 0.173; and high dose: $0.347 \mathrm{mg} / \mathrm{g}$ per d)). They were fed with a control diet with a normal $\mathrm{Ca}$ level (0.6\% Ca and 0.65\% P) (TD 98005; Teklad) $2 \mathrm{~d}$ before the treatments. During the treatment period, animals were pair-fed with the control diet, received treatment orally for 6 weeks and were allowed free access to water throughout

Bone properties of the left femur, tibia and lumbar spine region L1 were measured using StraTec XCT2000 machine (Norland Stratec Medizintechnik, GmbH). Mid-shaft and distal regions of femur and tibia were scanned using a developed protocol designed for studying isolated small bones ${ }^{(40)}$ The distal/proximal site was defined as $2.5 \mathrm{~mm}$ away from femur/tibia head. The mid-shaft was the middle region of each long bone. Total BMD, trabecular BMD, total cross-sectional area, trabecular cross-sectional area and stress-strain index (SSI) in the distal/proximal site were determined.

\section{Biomechanical measures of tibia mid-diaphysis}

Mechanical strength of mid-shaft tibia was measured using a specified three-point bending machine (Hounsfield Test Equipment), as previously described ${ }^{(41)}$. The anterior side, which was the point receiving compression, was placed upwards. A certain load was applied on the mid-shaft tibia until fracture occurred. All the specimens were pressed at a displacement of $5 \mathrm{~mm} / \mathrm{min}$ and a load-deformation curve was plotted simultaneously. Structural properties (including ultimate load and stiffness) were determined from the loaddeformation curve. The material properties were determined based on the calculations of the curve with beam bending theory such as flexural modulus. 


\section{Culture of rat osteoblastic UMR-106 cells and cell proliferation assay}

UMR-106 cells (ATCC no. CRL-1661) were routinely cultured in Dulbecco's modified Eagle's medium supplemented with $10 \%$ fetal bovine serum, penicillin $(100 \mathrm{U}(60 \mu \mathrm{g}) / \mathrm{ml})$ and streptomycin $(100 \mu \mathrm{g} / \mathrm{ml})$ at $37^{\circ} \mathrm{C}$ in a humidified atmosphere of $95 \%$ air and $5 \% \mathrm{CO}_{2}$, as previously described ${ }^{(36)}$. At confluence, the medium was changed to phenol red-free Dulbecco's modified Eagle's medium supplemented with 1\% dextrancharcoal-stripped serum fetal bovine serum for $24 \mathrm{~h}$. The cells were then treated with $\mathrm{E}_{2}(10 \mathrm{~nm})$, DFTF extracts, isolated compounds or vehicle in the presence or absence of ICI 182780 for $24 \mathrm{~h}$. The cell proliferation rate was measured by a CellTiter $96{ }^{\circledR}$ AQueous non-Radioactive Cell Proliferation Kit (Promega) with tetrazolium compound 3-(4,5-dimethylthiazol-2-yl)-5-(3-carboxymethoxy phenyl)-2-(4-sulphophenyl)$2 \mathrm{H}$ tetrazolium (MTS) and an electron coupling reagent (phenazine methosulphate). Cells were treated with MTS reagent and the absorbance was then recorded in a microplate reader at $490 \mathrm{~nm}$ after $2 \mathrm{~h}$ of incubation.

\section{Alkaline phosphatase assay}

ALP activity was measured directly on the monolayer of cell cultures on a ninety-six-well microplate after treatment with DFTF extract, isolated compounds, $\mathrm{E}_{2}(10 \mathrm{~nm})$ or vehicle in the presence or absence of ICI 182780 for $24 \mathrm{~h}$. The assay was carried out by incubating the cells with $10 \mathrm{~mm}$-p-nitrophenylphosphate for $30 \mathrm{~min}$ at $37^{\circ} \mathrm{C}$. The absorbance of colour change was measured at $405 \mathrm{~nm}$ in a microplate reader. A Bradford protein assay was carried out to normalise ALP expression and as ALP activity was expressed U/l per $\mu \mathrm{g}$ protein.

\section{Real-time quantitative $P C R$ analysis}

Total RNA was extracted from the treated cells using TRIzol ${ }^{\circledR}$ reagent according to the manufacturer's instructions (Invitrogen). A measure of $2 \mu \mathrm{g}$ of total RNA was reverse transcribed to complementary DNA using a high-capacity complementary
DNA reverse transcription kit (Applied Biosystems). The mRNA of receptor activator of NF- $\mathrm{BB}$ ligand (RANKL) and osteoprotegerin (OPG) was determined by quantitative realtime PCR using 7900HT Fast Real-time PCR system (Applied Biosystems). The complementary DNA was amplified with $600 \mathrm{~nm}$ of gene-specific primers: for OPG, sense: GACGAGATTGAGAGAACGAG, antisense: GGTGCTTGACTTTCTAGGTG; for RANKL, sense, TCAGGAGTTCCAGCTATGAT, antisense, CCATCAGCTGAAGATAGTCC; and for glyceraldehyde-3-phosphaste dehydrogenase, sense, TACATTTTGCTGATGACTGG, antisense, TGAATGGTAGgAGCTTGACT. The PCR programme was carried out as follows: denaturation $95^{\circ} \mathrm{C}$ for $20 \mathrm{~s}$, amplification for forty cycles $\left(95^{\circ} \mathrm{C}\right.$ for $1 \mathrm{~s} ; 53 / 60^{\circ} \mathrm{C}$ for $20 \mathrm{~s}$ and $72^{\circ} \mathrm{C}$ for $20 \mathrm{~s}$ ). Post-PCR dissociation curves were calculated to confirm the specificity of single-target amplification. The amount of complementary DNA was calculated by using a standard curve that was generated from the negative control group (C) ${ }^{(42)}$. Expression levels of $R A N K L$ and $O P G$ were normalised to the expression of glyceraldehyde-3-phosphaste dehydrogenase (GAPDH), a housekeeping gene. Modulation of osteoclastogenesis was presented as the ratio between the levels of $O P G$ to $R A N K L$ mRNA expression.

\section{Statistical analysis}

The in vivo data were analysed using one-way ANOVA followed by Tukey's post-test and the in vitro data were analysed by the non-paired Student's $t$ test between the $C$ and each treatment group using the GraphPad PRISM ${ }^{\circledR}$ software package (GraphPad Software, Inc.). Results were expressed as mean values with their standard errors. $P$ values $<0.05$ were considered to be significant.

\section{Results}

Effects of Drynaria fortunei total flavonoids on ovariectomy-induced changes in biochemical markers and uterus weight in mice

OVX significantly reduced the uterus index and increased the urinary $\mathrm{Ca}$ excretion in mice $(v$. sham, $P<0 \cdot 05)$ (Table 1 ).

Table 1. Effects of Drynaria fortunei total flavonoids (DFTF) on body weight, uterus weight, and serum and urinary biochemical markers in ovariectomised (OVX) mice*

(Mean values with their standard errors, $n 8$ )

\begin{tabular}{|c|c|c|c|c|c|c|c|c|c|c|c|c|c|c|}
\hline & \multicolumn{2}{|c|}{$\begin{array}{l}\text { Body weight } \\
\text { (\% change) }\end{array}$} & \multicolumn{2}{|c|}{$\begin{array}{l}\text { Uterus in } \\
(\mathrm{mg} / \mathrm{g})\end{array}$} & \multicolumn{2}{|c|}{$\begin{array}{l}\text { Serum Ca } \\
(\mathrm{mg} / \mathrm{l})\end{array}$} & \multicolumn{2}{|c|}{$\begin{array}{c}\text { Serum } P \\
(\mathrm{mg} / \mathrm{l})\end{array}$} & \multicolumn{2}{|c|}{$\begin{array}{l}\text { Urinary Ca/Cr } \\
\quad(\mathrm{mg} / \mathrm{mg})\end{array}$} & \multicolumn{2}{|c|}{$\begin{array}{l}\text { Urinary } \mathrm{P} / \mathrm{Cr} \\
(\mathrm{mg} / \mathrm{mg})\end{array}$} & \multicolumn{2}{|c|}{$\begin{array}{l}\text { Urinary Dpd/Cr } \\
\text { (mg/mg) }\end{array}$} \\
\hline & Mean & SEM & Mean & SEM & Mean & SEM & Mean & SEM & Mean & SEM & Mean & SEM & Mean & SEM \\
\hline Sham (veh) & 3.22 & 0.096 & $2 \cdot 31 \dagger$ & 0.32 & $70 \cdot 8$ & $2 \cdot 2$ & 103.6 & 4.6 & $0.55 \dagger$ & 0.05 & 6.37 & 0.61 & $25 \cdot 50$ & $2 \cdot 61$ \\
\hline OVX (veh) & 3.07 & 0.095 & $0.28 \ddagger$ & 0.04 & 66.9 & $3 \cdot 2$ & 88.6 & 4.8 & $0.85 \ddagger$ & 0.09 & $5 \cdot 65$ & 0.31 & 38.93 & 4.95 \\
\hline$E_{2}$ & $2 \cdot 41 \dagger \ddagger$ & 0.082 & $2 \cdot 69 \dagger$ & 0.18 & $64 \cdot 8$ & $2 \cdot 4$ & $107 \cdot 8$ & $6 \cdot 1$ & $0.50 \dagger$ & 0.05 & $4 \cdot 34$ & 0.40 & $20 \cdot 21 \dagger$ & 1.56 \\
\hline DFTF (low) & 3.04 & 0.088 & $0.35 \ddagger$ & 0.04 & 69.6 & 1.5 & $96 \cdot 1$ & 2.5 & 0.70 & 0.05 & 4.87 & 0.57 & 31.35 & 2.49 \\
\hline DFTF (medium) & $2 \cdot 83 \ddagger$ & 0.078 & $0.43 \ddagger$ & 0.08 & $77 \cdot 3 \ddagger$ & $2 \cdot 0$ & $96 \cdot 2$ & $5 \cdot 2$ & $0.55 \dagger$ & 0.05 & $4 \cdot 28$ & 0.67 & $21 \cdot 70 \dagger$ & 4.90 \\
\hline DFTF (high) & $2 \cdot 48 \dagger \ddagger$ & 0.092 & $0.58 \ddagger$ & 0.12 & $75 \cdot 2$ & $2 \cdot 2$ & $86 \cdot 7$ & $5 \cdot 3$ & $0.60 \dagger$ & 0.05 & $5 \cdot 24$ & 1.02 & 37.80 & 1.75 \\
\hline
\end{tabular}

Cr, creatinine; Dpd, deoxy-pyridinoline; sham (veh), sham-operated vehicle-treated; OVX (veh), OVX vehicle-treated; $E_{2}, 17 \beta-0 e s t r a d i o l ~(2 \mu \mathrm{g} / \mathrm{g}$ per d); DFTF (low): 0.087 mg/g per d; DFTF (medium), $0.173 \mathrm{mg} / \mathrm{g}$ per d; DFTF (high), $0.346 \mathrm{mg} / \mathrm{g}$ per d.

* Sham and OVX C57/BL6J mice were subjected to the following treatments for 6 weeks: sham (veh), OVX (veh), E 2 , DFTF (low), DFTF (medium), DFTF (high). Results were analysed by one-way ANOVA.

† Mean values were significantly differed compared with OVX (veh) $(P<0.05)$.

$\ddagger$ Mean values were significantly differed compared with Sham (veh) $(P<0.05)$. 
Table 2. Effects of Drynaria fortunei total flavonoids (DFTF) on bone mineral density (BMD), cross-sectional area, stress-strain index (SSI) of the distal femur, proximal tibia and lumbar spine region L1 in ovariectomised (OVX) mice*

(Mean values with their standard errors, $n 8$ )

\begin{tabular}{|c|c|c|c|c|c|c|c|c|c|c|c|c|}
\hline & \multicolumn{2}{|c|}{ Sham (veh) } & \multicolumn{2}{|c|}{ OVX (veh) } & \multicolumn{2}{|c|}{$E_{2}$} & \multicolumn{2}{|c|}{ DFTF (low) } & \multicolumn{2}{|c|}{ DFTF (medium) } & \multicolumn{2}{|c|}{ DFTF (high) } \\
\hline & Mean & SEM & Mean & SEM & Mean & SEM & Mean & SEM & Mean & SEM & Mean & SEM \\
\hline \multicolumn{13}{|l|}{ Total BMD $\left(\mathrm{mg} / \mathrm{cm}^{3}\right)$} \\
\hline Distal femur & $394.3 \dagger$ & $7 \cdot 2$ & $335.2 \ddagger$ & 6.5 & $453.4 † \ddagger$ & 8.5 & $377.4 \dagger$ & 4.5 & $395.6 \dagger$ & 4.8 & $394.3 \dagger$ & $7 \cdot 2$ \\
\hline Proximal tibia & 283.7 & $9 \cdot 8$ & 240.9 & 5.9 & $325 \cdot 5 \dagger \ddagger$ & $12 \cdot 7$ & 267.9 & 5.4 & $300.0 \dagger$ & $4 \cdot 1$ & $270 \cdot 9$ & 11.9 \\
\hline Lumbar spine L1 & $236.9 \dagger$ & $2 \cdot 0$ & $215 \cdot 0$ & $6 \cdot 4$ & $259 \cdot 1 \dagger \ddagger$ & 7.4 & 226.9 & $2 \cdot 0$ & $249 \cdot 1 \dagger$ & $1 \cdot 8$ & $241 \cdot 1 \dagger$ & $3 \cdot 6$ \\
\hline \multicolumn{13}{|c|}{ Trabecular BMD (mg/cm $\left.{ }^{3}\right)$} \\
\hline Distal femur & $404 \cdot 1 \dagger$ & $6 \cdot 2$ & $334.5 \ddagger$ & 9.9 & $463 \cdot 8 \dagger \ddagger$ & 13.7 & $381 \cdot 1 \dagger$ & $6 \cdot 0$ & $410.9 \dagger$ & 9.5 & $396.2 \dagger$ & $15 \cdot 9$ \\
\hline Proximal tibia & 286.7 & $8 \cdot 8$ & 237.8 & $8 \cdot 1$ & $333.6 \dagger$ & $19 \cdot 8$ & $285 \cdot 6$ & $4 \cdot 2$ & $321.2 \dagger$ & $8 \cdot 0$ & $296 \cdot 0 \dagger$ & $16 \cdot 5$ \\
\hline Lumbar spine L1 & ND & & & & & & & & & & & \\
\hline \multicolumn{13}{|c|}{ Total cross-sectional area $\left(\mathrm{mm}^{2}\right)$} \\
\hline Distal femur & 4.06 & 0.20 & 3.35 & 0.17 & 4.04 & $0 \cdot 12$ & $4.40 \dagger$ & 0.20 & $4.50 \dagger$ & 0.12 & 3.98 & 0.16 \\
\hline Proximal tibia & $4 \cdot 13$ & 0.58 & 2.79 & 0.49 & 3.75 & 0.58 & 4.22 & 0.42 & $5 \cdot 27 \dagger$ & 0.14 & $5.49 \dagger$ & 0.16 \\
\hline Lumbar spine L1 & 3.14 & 0.29 & $2 \cdot 15$ & 0.34 & $4.72 \dagger \ddagger$ & 0.48 & $3.57 \dagger$ & 0.22 & $4 \cdot 14 \dagger$ & 0.19 & $3.70 \dagger$ & 0.21 \\
\hline \multicolumn{13}{|c|}{ Trabecular cross-sectional area $\left(\mathrm{mm}^{2}\right)$} \\
\hline Distal femur & $1.83 \dagger$ & 0.11 & $1.30 \ddagger$ & 0.16 & 1.80 & 0.07 & 1.84 & 0.13 & $1.89 \dagger$ & 0.12 & 1.53 & 0.14 \\
\hline Proximal tibia & $1.94 \dagger$ & 0.22 & $1.03 \ddagger$ & 0.13 & 1.63 & 0.25 & $2 \cdot 22 \dagger$ & 0.07 & $2.33 \dagger$ & 0.07 & $2.45 \dagger$ & 0.07 \\
\hline Lumbar spine L1 & ND & & & & & & & & & & & \\
\hline \multicolumn{13}{|l|}{ SSI } \\
\hline Distal femur & $0.738 \dagger$ & 0.032 & $0.380 \ddagger$ & 0.049 & $0.714 \dagger$ & 0.055 & $0.700 \dagger$ & 0.069 & $0.763 \dagger$ & 0.036 & 0.615 & 0.046 \\
\hline Proximal tibia & 0.400 & 0.065 & 0.200 & 0.037 & 0.486 & 0.120 & 0.344 & 0.041 & $0.550 \dagger$ & 0.033 & 0.438 & 0.068 \\
\hline Lumbar spine L1 & 0.563 & 0.042 & 0.400 & 0.053 & $0.888 \dagger \ddagger$ & 0.089 & $0.580 \dagger$ & 0.040 & $0.700 \dagger$ & 0.024 & $0.650 \dagger$ & 0.038 \\
\hline
\end{tabular}

Sham (veh), sham-operated vehicle-treated; OVX (veh), OVX vehicle-treated; $E_{2}, 17 \beta$-oestradiol (2 $\mu \mathrm{g} / \mathrm{g}$ per d); DFTF (low), $0.087 \mathrm{mg} / \mathrm{g}$ per d; DFTF (medium), $0.173 \mathrm{mg} / \mathrm{g}$ per d; DFTF (high), 0.346 mg/g per d; ND, not determined. Sham (veh), sham-operated vehicle-treated; OVX (veh), OVX vehicle-treated; $E_{2}, 17 \beta-o e s t r a d i o l ~(2 \mu \mathrm{g} / \mathrm{g} \mathrm{per} \mathrm{d);} \mathrm{DFTF} \mathrm{(low),} 0.087 \mathrm{mg} / \mathrm{g} \mathrm{per} \mathrm{d;} \mathrm{DFTF} \mathrm{(medium),} 0.173 \mathrm{mg} / \mathrm{g} \mathrm{per} \mathrm{d;} \mathrm{DFTF} \mathrm{(high),} \mathrm{0.346} \mathrm{mg/g} \mathrm{per} \mathrm{d;} \mathrm{ND,} \mathrm{not} \mathrm{determined.}$
*Sham and OVX C57/BL6J mice were subjected to the following treatments for 6 weeks: sham (veh), OVX (veh), E $\mathrm{E}_{2}$, DFTF (low), DFTF (medium), DFTF (high). Samples were subjected to peripheral quantitative computed tomography measurement. Results were analysed by one-way ANOVA.

† Mean values were significantly different compared with OVX $(P<0.05)$.

$\ddagger$ Mean values were significantly different compared with sham $(P<0.05)$. 
$\mathrm{E}_{2}$ significantly increased the uterus index and reduced body weight gain, urinary $\mathrm{Ca}$ and Dpd level in OVX mice ( $v$. OVX, $P<0.05)$. DFTF at medium and high doses suppressed body weight gain $(v$. sham, $P<0.05)$ and urinary Ca excretion ( $v$. OVX, $P<0.05)$ in OVX mice. DFTF at the medium dose significantly increased serum Ca $(v$. sham, $P<0.05)$ and reduced urinary DPD ( $v$. OVX, $P<0.05)$ in OVX mice. Unlike $\mathrm{E}_{2}$, DFTF at all doses did not increase the uterus index in OVX mice.

\section{Effects of Drynaria fortunei total flavonoids on bone properties in ovariectomised mice}

OVX weakened bone quality in mice by significantly reducing the BMD, cross-sectional area and SSI at all three measured sites (distal femur, proximal tibia and lumbar spine L1) (v. sham, $P<0.05$ ) (Table 2 ). $\mathrm{E}_{2}$ significantly improved both total BMD and trabecular BMD of all measured sites in OVX mice ( $v$. OVX, $P<0 \cdot 05)$. Total cross-sectional area was found to be improved by $E_{2}$ only at the lumbar spine L1 site in OVX mice when compared with the sham or OVX group $(P<0.05)$. The SSI, which reflects torsional bone strength, was significantly increased by $\mathrm{E}_{2}$ at both the distal femur and lumbar spine L1 in OVX mice ( $v$. OVX, $P<0 \cdot 05)$. Similarly, DFTF at all doses were able to improve the bone quality in OVX mice (Table 2). DFTF at all doses significantly increased total BMD, trabecular BMD, total cross-sectional area and SSI of distal femur in OVX mice; trabecular cross-sectional area of proximal tibia; as well as total cross-sectional area and SSI of lumbar spine L1 in OVX mice. However, when considering the effectiveness of DFTF on all measured bone sites, DFTF at the medium dose was superior to other doses, as it could statistically increase the level of total and trabecular BMD, total and trabecular crosssectional area, as well as SSI in OVX mice ( $v$. OVX, $P<0 \cdot 05)$.

\section{Effects of Drynaria fortunei total flavonoids on biomechanical strength in ovariectomised mice}

OVX significantly reduced the ultimate load of the tibia diaphysis in mice ( $v$. sham, $P<0.05$ ) (Table 3 ). Treatment of

Table 3. Effects of Drynaria fortunei total flavonoids (DFTF) on biomechanical bone strength of the tibia diaphysis in ovariectomised (OVX) mice*

(Mean values with their standard errors, $n 8$ )

\begin{tabular}{llllll}
\hline & \multicolumn{2}{c}{ Ultimate load $(\mathrm{N})$} & & \multicolumn{2}{c}{ Stiffness $(\mathrm{N} / \mathrm{mm})$} \\
\cline { 2 - 3 } & Mean & SEM & & Mean & SEM \\
\hline Sham (veh) & $14.71 \dagger$ & 0.69 & & 23.28 & 4.90 \\
OVX (veh) & $11.73 \ddagger$ & 0.34 & & 14.89 & 1.71 \\
E $_{2}$ & $16.46 \dagger$ & 0.76 & & 18.83 & 1.53 \\
DFTF (low) & 13.79 & 0.66 & & $27.27 \dagger$ & 1.50 \\
DFTF (medium) & $14.80 \dagger$ & 0.77 & & 22.44 & 3.40 \\
DFTF (high) & $14.64 \dagger$ & 0.53 & & $29.94 \dagger$ & 1.87 \\
\hline
\end{tabular}

Sham (veh), sham-operated vehicle-treated; OVX (veh), OVX vehicle-treated; $E_{2}$ $17 \beta$-oestradiol ( $2 \mu \mathrm{g} / \mathrm{g}$ per d); DFTF (low), $0.087 \mathrm{mg} / \mathrm{g}$ per d; DFTF (medium), $0.173 \mathrm{mg} / \mathrm{g}$ per d; DFTF (high), $0.346 \mathrm{mg} / \mathrm{g}$ per $\mathrm{d}$.

* Sham (Veh) and OVX C57/BL6J mice were subjected to treatment with $E_{2}$, three doses of DFTF (low, medium and high) or its vehicle (OVX (veh)) for 6 weeks.

Tibias were subjected to a three-point bending machine. Results were analysed by one-way ANOVA.

† Mean values were significantly different compared with OVX $(P<0.05)$

$\ddagger$ Mean values were significantly different compared with sham $(P<0.05)$.
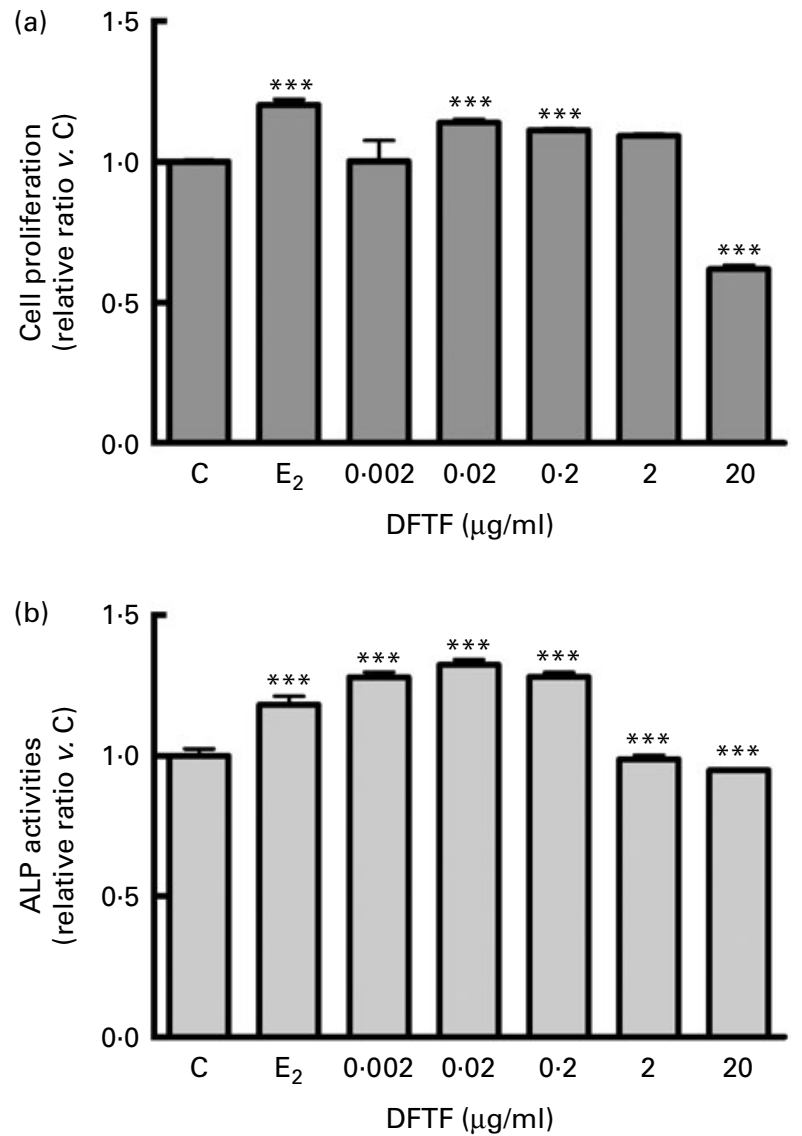

Fig. 2. Effects of Drynaria fortunei total flavonoids (DFTF) on cell proliferation and cell differentiation in rat osteoblast-like UMR-106 cells. DFTF were found to promote (a) cell proliferation and (b) cell differentiation in a dose-dependent manner. UMR-106 cells were treated with $17 \beta$-oestradiol $\left(E_{2}, 10 \mathrm{~nm}\right)$, vehicle and DFTF $(0.002-20 \mu \mathrm{g} / \mathrm{ml})$ for $24 \mathrm{~h}$. Cell proliferation was determined by 3-(4,5-dimethylthiazol-2-yl)-5-(3-carboxymethoxy phenyl)-2-(4-sulphophenyl)-2H tetrazolium (MTS) assay, while cell differentiation rate was determined by alkaline phosphatase (ALP) activity, with the results normalised by the amount of total protein. Results were obtained from three independent experiments. Values are means, with their standard errors represented by vertical bars $(n 8) .{ }^{* * *}$ Mean value was significantly different from that of the control group $(C):(P<0.001)$.

OVX mice with $\mathrm{E}_{2}$ significantly increased the ultimate load of the tibia diaphysis by $40 \%(v$. OVX, $P>0.001)$. DFTF at the medium and high doses significantly increased the ultimate load of tibia diaphysis by 26 and $24 \%$ ( $v$. OvX, $P>0.05)$, respectively. DFTF, but not $\mathrm{E}_{2}$, significantly increased the stiffness of the tibia diaphysis in OVX mice, although the stiffness was not significantly reduced by OVX in mice. Significant stimulatory effects on the stiffness of tibia by $83 \%(v$. OVX, $P>0.05)$ and $100 \%$ ( $v$. OVX, $P>0.001)$ were observed in mice treated with the low and high doses of DFTF treatment, respectively.

\section{Effects of Drynaria fortunei total flavonoids and isolated compounds on cell proliferation in rat osteoblast-like UMR-106 cells}

DFTF at 0.02 to $0.2 \mu \mathrm{g} / \mathrm{ml}$ increased cell proliferation in UMR-106 cells (Fig. 2(a), $P<0.001$ ), but a further increase 
in the concentration reduced cell proliferation. All three isolated compounds stimulated UMR-106 cell proliferation in a dose-dependent manner. As expected, naringin stimulated cell proliferation at $10^{-8}$ to $10^{-6} \mathrm{M}$ (Table 4). Compound 1 significantly induced cell growth from $10^{-12} \mathrm{M}$ and increased by $90 \%$ at $10^{-8} \mathrm{M}$ (Table $4, P<0 \cdot 001$ ). Compound 2 also significantly induced cell growth at $10^{-12}$ to $10^{-6} \mathrm{M}$, but the maximal fold of induction at $10^{-10} \mathrm{M}$ was only $27 \%$ (Table 4 ).

\section{Effects of Drynaria fortunei total flavonoids and isolated compounds on alkaline phosphatase activity in UMR-106 cells}

DFTF significantly increased ALP activity in UMR-106 cells at all tested concentrations from 0.002 to $0.2 \mu \mathrm{g} / \mathrm{ml}$ (Fig. 2(b), $P<0.001)$ and the maximal induction was at $0.02 \mu \mathrm{g} / \mathrm{ml}$, with an increase of $32 \%$. Naringin stimulated ALP activity in a dose-dependent manner, with a maximal increase of $12 \%$ at $10^{-6} \mathrm{M}$ in the UMR-106 cells (Table $4, P<0 \cdot 001$ ). Compound 1 was more active at lower concentration, which induced ALP activity by $48 \%$ at $10^{-14} \mathrm{M}$ ( $v$. C, $P<0 \cdot 001$, Table 4 ). The fold of induction of ALP activity declined with increasing concentration of compound 1. Compound 2 stimulated ALP activity in a dose-dependent manner and reached the maximum induction by $42 \%$ at $10^{-8} \mathrm{M}(v$. C, $P<0 \cdot 001$, Table 4$)$.

\section{Effects of ICI 182780 on the stimulatory effects induced by} Drynaria fortunei total flavonoids and isolated compounds in UMR-106 cells

To determine if the stimulatory action of DFTF and isolated compounds in UMR-106 cells were mediated via ER, cells treated with optimal concentrations of respective treatment were co-treated with a specific ER antagonist, ICI 182780. As shown in Fig. 3(a), the stimulatory actions of $10 \mathrm{~nm}-\mathrm{E}_{2}$, $0.02 \mu \mathrm{g} / \mathrm{ml}$ DFTF, $10 \mathrm{~nm}$-naringin, $10 \mathrm{~nm}$-compound 1 and $0 \cdot 1 \mathrm{~nm}$-compound 2 on cell proliferation were completely abolished by co-treatment with ICI 182780 . The results suggest that their stimulatory actions on osteoblastic cell proliferation are mediated via ER. Similarly, the stimulatory actions of $10 \mathrm{nM}-\mathrm{E}_{2}, \quad 0.02 \mu \mathrm{g} / \mathrm{ml}$ DFTF and $10 \mathrm{~nm}$-naringin on ALP activity were abolished in the presence of ICI 182780 in UMR-106 cells (Fig. 3(b)). However, the stimulatory effects of compounds 1 and 2 on ALP activity in UMR-106 cells were not abolished by co-treatment with ICI 182780. The results indicated that the stimulatory actions of $E_{2}$, DFTF and naringin, but not compounds 1 and 2, on osteoblastic differentiation were ER dependent.

Effects of Drynaria fortunei total flavonoids and isolated compounds on osteoprotegrin and receptor activator of $N F-\kappa B$ ligand mRNA expression in UMR-106 cells

A measure of $10 \mathrm{~nm}$ of $\mathrm{E}_{2}$, DFTF $(0.02 \mu \mathrm{g} / \mathrm{ml}), 10 \mathrm{~nm}-\mathrm{com}-$ pound 1 and $0 \cdot 1 \mathrm{~nm}$-compound 2 , but not naringin (10 nM), significantly increased $O P G$ mRNA expression in UMR-106 cells ( $v$. C, $P<0.05$, Fig. 4(a)). The stimulatory effects on $O P G$ mRNA expression by $\mathrm{E}_{2}$, compounds 1 and 2 were reduced in the presence of the ER antagonist. However, the stimulatory effects of compound 1 on $O P G$ mRNA expression in UMR-106 cells were only suppressed by $18 \%$ in the presence of ICI 182780. Moreover, $10 \mathrm{~nm}-\mathrm{E}_{2}$ and $10 \mathrm{~nm}$-naringin could significantly suppress RANKL mRNA expression in UMR-106 cells by 10 and $52 \%$ (v. C, $P<0 \cdot 05$, Fig. 4(b)), respectively. DFTF did not alter RANKL mRNA expression in UMR-106 cells. Compounds 1 and 2 significantly induced RANKL expression by 38 and 58\% (v. C, P<0.05, Fig. 4(b)), respectively. ICI 182780 itself did not alter the mRNA expression level of $R A N K L$. This implies that the role of ICI is passive and the effects of ICI 182780 on RANKL mRNA expression level could only be demonstrated in the presence of oestrogen-like agents. In contrast, co-treatment with ICI 180780 significantly increased $R A N K L$ mRNA expression in cells treated with compound 2 and significantly decreased RANKL mRNA expression in cells treated with compound 1 . The results suggest that the actions of compounds 1 and 2

Table 4. Effects of Drynaria fortunei isolated compounds on cell proliferation and cell differentiation in rat osteoblast-like UMR-106 cells $†$ (Mean values with their standard errors, $n 8$ )

\begin{tabular}{|c|c|c|c|c|c|c|c|c|c|c|c|c|}
\hline & \multicolumn{2}{|c|}{0 (M) } & \multicolumn{2}{|c|}{$10^{-14}(\mathrm{M})$} & \multicolumn{2}{|c|}{$10^{-12}(\mathrm{M})$} & \multicolumn{2}{|c|}{$10^{-10}(\mathrm{M})$} & \multicolumn{2}{|c|}{$10^{-8}(\mathrm{M})$} & \multicolumn{2}{|c|}{$10^{-6}(\mathrm{M})$} \\
\hline & Mean & SEM & Mean & SEM & Mean & SEM & Mean & SEM & Mean & SEM & Mean & SEM \\
\hline \multicolumn{13}{|l|}{ Cell proliferation } \\
\hline$E_{2}$ & 1.00 & 0.04 & \multicolumn{2}{|c|}{ - } & \multicolumn{2}{|c|}{ - } & \multicolumn{2}{|c|}{ - } & $1 \cdot 31^{\star *}$ & 0.07 & \multicolumn{2}{|c|}{-} \\
\hline Naringin & - & - & 1.01 & 0.05 & 0.99 & 0.07 & 1.04 & 0.07 & $1 \cdot 16^{*}$ & 0.01 & $1 \cdot 18^{*}$ & 0.02 \\
\hline Compound 1 & - & - & 1.08 & 0.03 & $1 \cdot 20^{*}$ & 0.07 & $1.46^{\star \star *}$ & 0.02 & $1.90^{\star \star *}$ & 0.07 & $1.48^{\star * \star}$ & 0.08 \\
\hline Compound 2 & - & - & $1 \cdot 16$ & 0.05 & $1 \cdot 25^{\star}$ & 0.06 & $1 \cdot 27^{*}$ & 0.06 & $1 \cdot 22$ & 0.08 & $1 \cdot 28^{*}$ & 0.05 \\
\hline \multicolumn{13}{|c|}{ Cell differentiation } \\
\hline$E_{2}$ & 1.00 & 0.02 & \multicolumn{2}{|c|}{-} & \multicolumn{2}{|c|}{-} & \multicolumn{2}{|c|}{-} & $1 \cdot 23^{\star \star}$ & 0.06 & \multicolumn{2}{|c|}{ - } \\
\hline Naringin & - & - & 1.03 & 0.07 & 0.97 & 0.06 & 1.09 & 0.04 & $1 \cdot 10^{\star *}$ & 0.02 & $1 \cdot 12^{* \star *}$ & 0.01 \\
\hline Compound 1 & - & - & $1.48^{* * *}$ & 0.03 & $1 \cdot 27^{\star \star}$ & 0.06 & $1 \cdot 21^{\star \star}$ & 0.06 & $1 \cdot 19^{\star \star}$ & 0.04 & $1 \cdot 19^{\star *}$ & 0.04 \\
\hline Compound 2 & - & - & $1 \cdot 32^{\star *}$ & 0.03 & $1 \cdot 32^{\star *}$ & 0.04 & $1 \cdot 32^{\star \star *}$ & 0.02 & $1.42^{\star \star \star}$ & 0.03 & $1.41^{* \star *}$ & 0.01 \\
\hline
\end{tabular}

$E_{2}, 17 \beta$-oestradiol.

Mean values were significantly different compared with the control group: ${ }^{\star} P<0.05,{ }^{\star \star} P<0.01,{ }^{* \star *} P<0.001$.

† UMR-106 cells were treated with $E_{2}(10 \mathrm{nM})$, vehicle, naringin $\left(10^{-14}\right.$ to $\left.10^{-6} \mathrm{M}\right)$, compound $1\left(10^{-14}\right.$ to $\left.10^{-6} \mathrm{M}\right)$ and compound $2\left(10^{-14}\right.$ to $\left.10^{-6} \mathrm{M}\right)$ for $24 \mathrm{~h}$. Cell proliferation was determined by 3-(4,5-dimethylthiazol-2-yl)-5-(3-carboxymethoxy phenyl)-2-(4-sulphophenyl)-2H tetrazolium assay, while cell differentiation rate was determined by alkaline phosphatase activity with the results being normalised by the amount of total protein. Results were obtained from three independent experiments. 

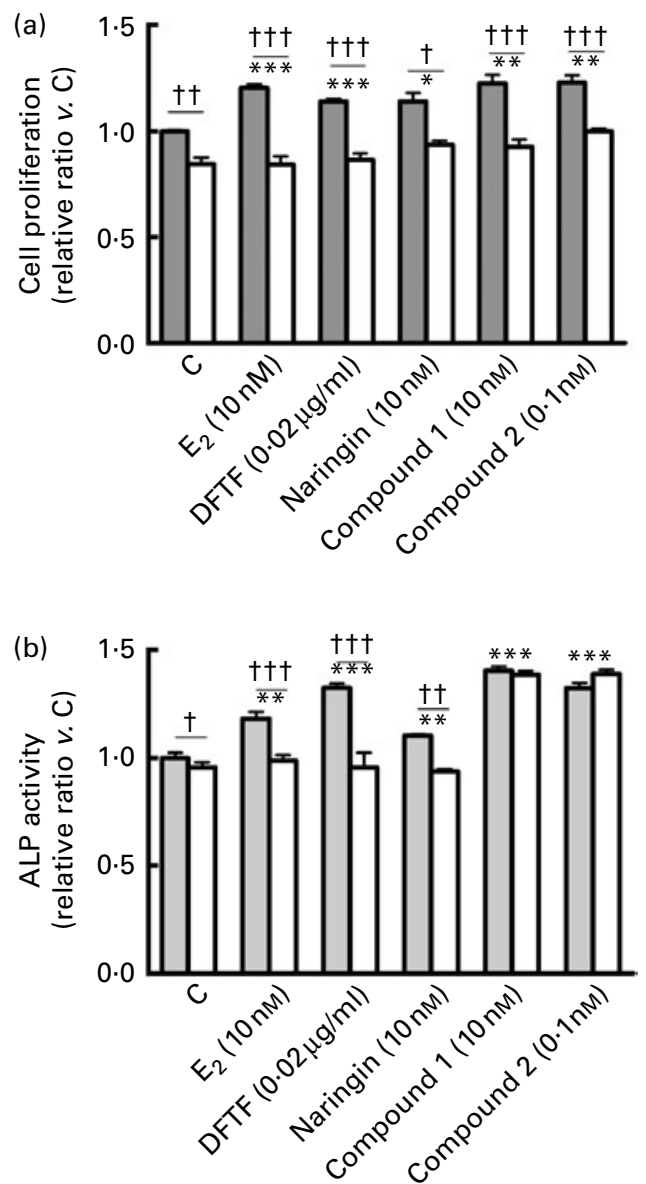

Fig. 3. Effects of $\mathrm{ICI} 182780$ on the stimulatory actions of Drynaria fortunei total flavonoids (DFTF) and isolated compounds on (a) cell proliferation and (b) differentiation in UMR-106 cells. The abolishment of cell proliferation effects was observed in DFTF and its active compounds. However, the abolishment of cell differentiation effects was only observed in DFTF and naringin, but not in compounds 1 and 2. (a) UMR-106 cells were treated with $17 \beta$-oestradiol $\left(E_{2}, 10 \mathrm{nM}\right)$, vehicle, DFTF $(0.02 \mu \mathrm{g} / \mathrm{ml})$, naringin $(10 \mathrm{nM})$, compound $1(10 \mathrm{~nm})$ and compound $2(0.1 \mathrm{~nm})$ for $24 \mathrm{~h}$ in the presence or absence of ICl $182780(10 \mu \mathrm{M})$. Results were obtained from three independent experiments. Values are means, with their standard errors represented by vertical bars $(n 6)$. Mean values were significantly different compared with the control group $(C):{ }^{*} P<0.05,{ }^{* \star} P<0.01,{ }^{* \star *} P<0.001$. Mean values were significantly different compared between treatment groups with $(\square)$ and without $\mathrm{ICl}(\square): ~ † P<0.05$, †† $P<0.01$ and $\dagger \dagger \dagger P<0.001)$.

on RANKL mRNA expression might not fully mimic the effects of $E_{2}$ in UMR-106 cells. The results also indicate that the regulation of RANKL mRNA in UMR-106 cells is complex and appears to be differentially regulated by different compounds as well as during co-treatment with ICI 182780. The ratio of the expression level of $O P G$ to $R A N K L$ is used to assess the effects of different treatment on osteoclastogenesis ${ }^{(36)}$. As shown in Fig. 4(c), treatment of UMR-106 cells with $10 \mathrm{~nm}$ of $\mathrm{E}_{2}, 0.02 \mu \mathrm{g} / \mathrm{ml}$ DFTF, $10 \mathrm{~nm}$-naringin, $10 \mathrm{~nm}$-compound 1 and $0 \cdot 1 \mathrm{~nm}$-compound 2 significantly induced the ratio of OPG:RANKL mRNA expression ( $v$. C, $P<0.05$ ), suggesting their inhibitory actions on osteoclastogenesis. Moreover, COtreatment of UMR-106 cells with ICI 182780 significantly reduced the stimulatory effects of all treatment on the ratio of OPG:RANKL mRNA ( $v$. respective group, $P<0.05)$
(Fig. 4(c)), suggesting that their actions were mediated via ER. It should be noted that the blocking effects by ICI 182780 were almost complete in all treatment groups, except for treatment with DFTF $(0.02 \mu \mathrm{g} / \mathrm{ml})$. The results suggest that the effects of DFTF on osteoclastogenesis might involve other signalling pathways.

\section{Discussion}

The present study systematically evaluated the osteoprotective effects and mechanism of actions of DFTF in OVX mice and in rat osteoblast-like UMR-106 cells. In addition, the oestrogenic effects of three active ingredients in DFTF on UMR-106 cells were characterised. The present results clearly showed that DFTF was effective in protecting against OVX-induced loss in bone properties as well as increase in urinary Ca excretion in OVX mice. In addition, the present study showed that DFTF as well as its three active ingredients mimicked oestrogen in stimulating cell proliferation, ALP activity and OPG/RANKL mRNA expression in UMR-106 cells, suggesting that it may exert oestrogen-like effects in promoting osteoblastic functions and inhibiting osteoclastogenesis.

Treatment of OVX mice with DFTF for 6 weeks was shown to improve bone quality at the distal femur, proximal tibia and lumbar spine in OVX mice. Total and trabecular BMD were significantly increased in OVX mice at the distal femur by treatment with DFTF at all doses and at the proximal tibia by treatment with DFTF at the medium and high doses. The positive effects of DFTF on total and trabecular cross-sectional area were dose-dependent as well as site-dependent in OVX mice. Specifically, DFTF at the low and medium doses significantly increased total cross-sectional area at the distal femur, while DFTF at the medium and high doses increased the parameter at the proximal tibia. As for the lumbar spine, DFTF at the medium and high doses increased total BMD and total cross-sectional area, while DFTF at the low dose only increased total cross-sectional area but not total BMD in OVX mice. The effects of DFTF on SSI in OVX mice were also site-dependent. DFTF at all doses significantly increased SSI at the distal femur and lumbar spine. In addition, DFTF also increased biomechanical strength at the tibia diaphysis in OVX mice. The present results are in agreement with those reported by others ${ }^{(43,44)}$. Xie et al. ${ }^{(43)}$ reported that $0 \cdot 108$ and $0 \cdot 216 \mathrm{~g} / \mathrm{kg}$ per d DFTF significantly restored BMD in the distal femur and lumbar spine of OVX rats by $8-15$ and $27-36 \%$, respectively. Our experiments also revealed similar effects at these sites in OVX mice treated with the medium and high dosages.

The present results showed that oestrogen as well as DFTF at the medium and high dosages (0.173 and $0.346 \mathrm{mg} / \mathrm{g}$ per $\mathrm{d})$ ) could prevent OVX-induced weight gain in mice. As the animals were pair-fed in the present study, it appeared that DFTF was able to suppress weight gain associated with the changes in energy metabolism in mice during oestrogen deficiency. Similarly, both oestrogen and DFTF at the medium and high doses could reduce OVX-induced urinary Ca loss. Most importantly, the beneficial effects of DFTF on bone, body weight control as well as urinary Ca loss were not associated 

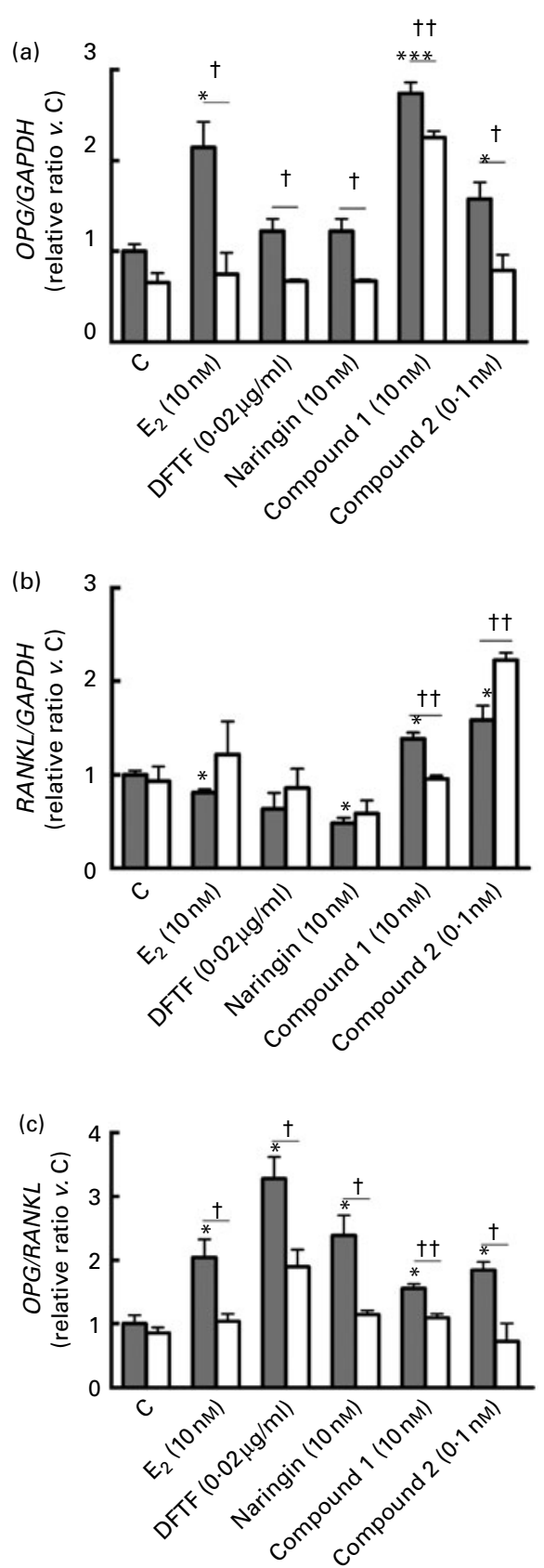

Fig. 4. Effects of Drynaria fortunei total flavonoids (DFTF) on osteoprotegerin $(O P G)$ and receptor activator of NF-kB ligand (RANKL) mRNA expression in UMR-106 cells. DFTF increased OPG mRNA expression, while naringin decreased RANKL mRNA expression. Isolated compounds 1 and 2 increased $O P G$ and RANKL mRNA expression. The overall mRNA expressions of $O P G$ and $R A N K L$ were all up-regulated by DFTF, naringin, compounds 1 and 2. These effects were blocked by oestrogen receptor (ER) antagonist. UMR-106 cells were treated with $17 \beta$-oestradiol $\left(E_{2}, 10 \mathrm{nM}\right)$, vehicle, DFTF $(0.02 \mu \mathrm{g} / \mathrm{ml})$, naringin (10 nM), compound $1(10 \mathrm{~nm})$ and compound $2(0.1 \mathrm{nM})$ for $24 \mathrm{~h}$ in the presence or absence of ICl $182780(10 \mu \mathrm{M})$. The samples were subjected to quantitative real-time PCR analysis of $O P G$, RANKL and glyceraldehyde-3-phosphaste dehydrogenase (GAPDH) mRNA expression. The (a) OPG mRNA and (b) RANKL mRNA expression as well as (c) the ratio of OPG:RANKL mRNA were normalised by an internal control gene, GAPDH. Results were obtained from two independent experiments. Values are means, with their standard errors represented by vertical bars $(n 6)$. Mean values were significantly different compared with the control group (C): ${ }^{*} P<0.05,{ }^{* * *} P<0.001$. Mean values were significantly different compared among treatment groups with ( $\square$ ) and without $\mathrm{ICI}(\square)$ : $† P<0.05$, $\uparrow \dagger P<0.01$. with an induction of the uterus index in mice. Thus, it appears that the oestrogen-like actions of DFTF in vivo might be distinct from those of oestrogen, and the present results suggest that DFTF exerts oestrogen-like effects in a tissue-specific manner.

The present results showed that DFTF as well as the three isolated active ingredients exerted direct stimulatory effects on osteoblastic cell proliferation and differentiation in rat osteoblast-like UMR-106 cells. The induction of osteoblastic differentiation and mineralisation by a crude extract of DF was reported to be mediated via the regulation of bone morphogenetic protein-2 in pre-osteoblastic MC3T3-E1 cells ${ }^{(17)}$. In addition, serum from DFTF-treated rats was shown to promote proliferation and differentiation of cultured osteoblasts extracted from newborn Sprague-Dawley rats ${ }^{(44)}$. The present results, together with those reported by others ${ }^{(17,23)}$, clearly indicated that $\mathrm{DF}$, its isolated ingredients as well as metabolites exert direct effects on osteoblastic cell proliferation and differentiation.

Naringin, one of the three isolated active ingredients in DFTF, was repeatedly shown in our previous study ${ }^{(26,45)}$ as well as others ${ }^{(34,35,37)}$ to exert direct effects on osteoblastic cell proliferation and differentiation in vitro. Our recent studies $^{(26,29,30)}$ identified bioactive ingredients in DFTF that account for its osteoprotective activities, which include flavonoids ${ }^{(26,29)}$ and phenylpropanoids ${ }^{(30)}$ such as naringenin, kurarinone, kushennol F, xanthogalenol, sophoraflavanone $G$ and ferulic acid glucoside. The present study further investigated the dose-response of oestrogen-like effects of two isolated active compounds, namely, compound 1 and compound 2, in UMR-106 cells. The present results showed that compound 1 was highly potent in stimulating osteoblastic cell proliferation and differentiation, while compound 2 was also highly active in stimulating osteoblastic cell differentiation.

OPG and RANKL are identified as the dominant and final mediators of osteoclastogenesis ${ }^{(46)}$. The secretion of OPG by osteoblastic cells could block the interaction of RANKL with its functional receptor RANK, expressed on the osteoclastic cell surface, thereby inhibiting osteoclastogenesis. The regulations of osteoclasteogenesis through OPG and RANKL are found to be ER dependent ${ }^{(47)}$. Studies by Chen et al. ${ }^{(47)}$ showed that genistein and daidzein at $10 \mathrm{~nm}$ induced $O P G$ mRNA expression in human osteoblastic FOB cell lines in an ER-dependent manner. Similarly, the present study demonstrated that DFTF significantly induced the ratio of $O P G$ :RANKL mRNA expression in osteoblastic cells. Such effects might be due to the presence of naringin as well as compounds 1 and 2 in DFTF, as all three isolated compounds were also effective in inducing the ratio by mimicking the effects of oestrogen. The results also suggest that DFTF not only exerted positive effects on bone formation, but also negatively modulated bone resorption through its action on $O P G / R A N K L$ mRNA expression. Such observations were in agreement with those reported by Zhu et al. ${ }^{(48)}$ and Xie et $a l .{ }^{(43)}$. Total flavones of DF were shown to up-regulate bone-related gene expressions that are involved in bone formation (such as Smad1 and Smad5) ${ }^{(48)}$, suppress the circulatory level of cytokines involved in inducing bone resorption (TNF- $\alpha$ and IL-6) and stimulate the level of the 
cytokine (IL-4) associated with the suppression of bone resorption in OVX rats ${ }^{(43)}$.

The present results demonstrated that DFTF can exert positive effects in bone via ER-dependent pathways. The present study demonstrated that the stimulatory effects of DFTF on cell proliferation, differentiation as well as $O P G: R A N K L$ ratio in UMR-106 cells could be blocked by co-treatment with ICI 182780, thus providing evidence for the involvement of ER in mediating the actions of DFTF. In addition, the present results showed that the actions of compounds 1 and 2 on osteoblastic proliferation, but not on differentiation, were abolished in the presence of ICI 182780. The results suggest that the actions of compounds 1 and 2 might be distinct from those reported for naringin ${ }^{(10)}$. Taken together, the present results indicated that DFTF and its isolated compounds behave as phyto-oestrogens in stimulating ER-dependent actions in bone cells.

The present study clearly demonstrated that DFTF is effective in protecting against OVX-induced bone loss in mice and exerts direct effects in regulating osteoblastic cell growth in an ER-dependent manner. The optimal dose of DFTF for achieving bone-protective effects at three measured sites (distal femur, proximal tibia and lumbar spine) in OVX mice was shown to be $0.173 \mathrm{mg} / \mathrm{g}$ per d). Our previous studies have identified the major active ingredients in DFTF that exert direct effects on osteoblastic cells ${ }^{(28-30)}$. The oestrogen-like anabolic actions of three of the isolated compounds in UMR106 cells were also demonstrated in the present study. Thus, with the well-defined chemical composition, confirmed efficacy in preclinical studies as well as elucidated mechanism of actions, DFTF appears to be a promising agent for the management of postmenopausal osteoporosis. Future studies will be needed to evaluate the clinical efficacy of DFTF for the treatment of osteoporosis in postmenopausal women.

\section{Acknowledgements}

The present work was supported by the National Science Foundation China/Research Grant Council (N_PolyU536/04), HKSAR and the Niche Area Fund (I-BB8N) as well as a Research Studentship (RPC9) from The Hong Kong Polytechnic University. K.-C. W. performed the majority of the laboratory work and contributed to the analysis of data and the writing of the manuscript. W.-Y. P. and S.-K. M. participated in both the cell culture and animal experiments in the present study. X.-L. W. performed the preparation of total flavonoids fraction as well as isolated compounds from $D$. fortunei total extract. W.-P. L. conduced some of the laboratory work. Hung-Kay Chow supervised the measurement and analysis of biomechanical strength of bone specimen. P.-C. L. played a significant role in the design of the study as well as the analysis of bone specimens using peripheral quantitative computed tomography. X.-S. Y. was a co-investigator and grant holder and played a significant role in the design and performance of the study. M.-S. W. was the principal investigator and grant holder and played a major role in the design and performance of the study, interpretation of the results and the writing of the paper. The authors have no conflicts of interest to declare.

\section{References}

1. Banu J, Varela E \& Fernandes G (2012) Alternative therapies for the prevention and treatment of osteoporosis. Nutr Rev 70, 22-40.

2. Khosla S (2010) Update on estrogens and the skeleton. J Clin Endocrinol Metab 95, 3569-3577.

3. Al-Anazi AF, Qureshi VF, Javaid K, et al. (2011) Preventive effects of phytoestrogens against postmenopausal osteoporosis as compared to the available therapeutic choices: an overview. J Nat Sci Biol Med 2, 154-163.

4. Gass M \& Dawson-Hughes B (2006) Preventing osteoporosis-related fractures: an overview. Am J Med 119, S3-S11.

5. Cassidy A (2003) Dietary phytoestrogens and bone health. $J$ Br Menopause Soc 9, 17-21.

6. Zhang Y, Chen WF, Lai WP, et al. (2008) Soy isoflavones and their bone protective effects. Inflammopharmacology 16, 213-215.

7. Zhang Y, Li Q, Wan HY, et al. (2009) Genistein and a soy extract differentially affect three-dimensional bone parameters and bone-specific gene expression in ovariectomized mice. J Nutr 139, 2230-2236.

8. Lampe JW (2003) Isoflavonoid and lignan phytoestrogens as dietary biomarkers. J Nutr 133, Suppl. 3, 956S-964S.

9. Mok SK, Chen WF, Lai WP, et al. (2010) Icariin protects against bone loss induced by oestrogen deficiency and activates oestrogen receptor-dependent osteoblastic functions in UMR 106 cells. Br J Pharmacol 159, 939-949.

10. Pang WY, Wang XL, Mok SK, et al. (2010) Naringin improves bone properties in ovariectomized mice and exerts oestrogen-like activities in rat osteoblast-like (UMR-106) cells. $\mathrm{Br}$ J Pharmacol 159, 1693-1703.

11. Mei J, Yeung SSC \& Kung AWC (2001) High dietary phytoestrogen intake is associated with higher bone mineral density in postmenopausal but not premenopausal women. J Clin Endocrinol Metab 86, 5217-5221.

12. Zhang Y, Li Q, Li X, et al. (2010) Erythrina variegata extract exerts osteoprotective effects by suppression of the process of bone resorption. BrJ Nutr 104, 965-971.

13. Chen WF, Mok SK, Wang XL, et al. (2011) Total flavonoid fraction of the Herba epimedii extract suppresses urinary calcium excretion and improves bone properties in ovariectomised mice. Br J Nutr 105, 180-189.

14. Zhang Y, Li Q, Wan HY, et al. (2011) Study of the mechanisms by which Sambucus williamsii HANCE extract exert protective effects against ovariectomy-induced osteoporosis in vivo. Osteoporos Int 22, 703-709.

15. Zhou Q (2003) Clinical application of Drynaria in orthopedics and traumatology. J Tradit Chin Orthop Traumatol 15, 59 .

16. Sun JS, Dong GC, Lin CY, et al. (2003) The effect of Gu-Sui$\mathrm{Bu}$ (Drynaria fortunei J. Sm) immobilized modified calcium hydrogenphosphate on bone cell activities. Biomaterials $\mathbf{2 4}$, 873-882.

17. Jeong JC, Lee JW, Yoon CH, et al. (2004) Drynariae rhizoma promotes osteoblast differentiation and mineralization in MC3T3-E1 cells through regulation of bone morphogenetic protein-2, alkaline phosphatase, type I collagen and collagenase-1. Toxicol In Vitro 18, 829-834.

18. Jeong JC, Lee JW, Yoon CH, et al. (2005) Stimulative effects of Drynariae rhizoma extracts on the proliferation and differentiation of osteoblastic MC3T3-E1 cells. J Ethnopharmacol 96, 489-495.

19. Jeong JCLB, Yoon CH, Kim HM, et al. (2005) Effects of Drynariae rhizoma on the proliferation of human bone cells and the immunomodulatory activity. Pharm Res 51, 125-136. 
20. Wong RW \& Rabie AB (2006) Systemic effect of crude extract from rhizome of Drynaria fortunei on bone formation in mice. Phytother Res 20, 313-315.

21. Wong RW, Rabie B, Bendeus M, et al. (2007) The effects of rhizoma Curculiginis and rhizoma Drynariae extracts on bones. Chin Med 2, 13.

22. Sun JHW \& Liu K (2008) The research of Drynaria total flavonoids and osteoporosis research. Chin J Osteo 14, $763-766$.

23. Chen LLLL, Ding PH, Tang Q, et al. (2011) Osteogenic effect of Drynariae rhizome extracts and naringin on MC3T3-E1 cells and an induced rat alveolar bone resorption model. Arch Oral Biol 56, 1655-1662.

24. Guo D, Wang J, Wang X, et al. (2011) Double directional adjusting estrogenic effect of naringin from rhizoma Drynariae (Gusuibu). J Ethnopharmacol 138, 451-457.

25. Jeong JC, Kang SK, Youn CH, et al. (2003) Inhibition of Drynariae rhizoma extracts on bone resorption mediated by processing of cathepsin $\mathrm{K}$ in cultured mouse osteoclasts. Int Immunopharmacol 3, 1685-1697.

26. Wang XL, Wang NL, Zhang Y, et al. (2008) Effects of eleven flavonoids from the osteoprotective fraction of Drynaria fortunei (KUNZE) J. SM. on osteoblastic proliferation using an osteoblast-like cell line. Chem Pharm Bull (Tokyo) 56, $46-51$.

27. Eun Ju Chang WJL, Sung Hee Cho, Sang Won Choi. (2003) Proliferative effects of flavan-3-ols and propelargonidins from rhizomes of Drynaria fortunei on MCF-7 and osteoblastic cells. Arch Pharm Res 26, 620-630.

28. Wang XL, Wang NL, Gao H, et al. (2010) Phenylpropanoid and flavonoids from osteoprotective fraction of Drynaria fortunei. Nat Prod Res 24, 1206-1213.

29. Wang X, Zhen L, Zhang G, et al. (2011) Osteogenic effects of flavonoid aglycones from an osteoprotective fraction of Drynaria fortunei - an in vitro efficacy study. Phytomedicine 18, 868-872.

30. Wang XLWN, Wong MS \& Yao XS (2008) Phenylpropanoid compounds isolated from Drynaria fortunei and their proliferation effects on UMR 106 cells. J Shenyang Pharm Univ 25, 24-29.

31. Lu Y, Zhang C, Bucheli P, et al. (2006) Citrus flavonoids in fruit and traditional Chinese medicinal food ingredients in China. Plant Foods Hum Nutr 61, 57-65.

32. Wei M, Yang Z, Li P, et al. (2007) Anti-osteoporosis activity of naringin in the retinoic acid-induced osteoporosis model. Am J Chin Med 35, 663-667.

33. Mandadi K, Ramirez M, Jayaprakasha GK, et al. (2009) Citrus bioactive compounds improve bone quality and plasma antioxidant activity in orchidectomized rats. Phytomedicine 16, $513-520$.
34. Wu JB, Fong YC, Tsai HY, et al. (2008) Naringin-induced bone morphogenetic protein-2 expression via PI3K, Akt, c-Fos/c-Jun and AP-1 pathway in osteoblasts. EurJ Pharmacol $\mathbf{5 8 8}, 333-341$.

35. Li L, Zeng Z \& Cai G (2011) Comparison of neoeriocitrin and naringin on proliferation and osteogenic differentiation in MC3T3-E1. Phytomedicine 18, 985-989.

36. Xie F, Wu CF, Lai WP, et al. (2005) The osteoprotective effect of Herba epimedii (HEP) extract in vivo and in vitro. Evid Based Complement Alternat Med 2, 353-361.

37. Wong RW \& Rabie $\mathrm{AB}$ (2006) Effect of naringin on bone cells. J Orthop Res 24, 2045-2050.

38. Chang EJ, Lee WJ, Cho SH, et al. (2003) Proliferative effects of flavan-3-ols and propelargonidins from rhizomes of Drynaria fortunei on MCF-7 and osteoblastic cells. Arch Pharm Res 26, 620-630.

39. Kosuge K, Mitsunaga K, Koike K, et al. (1994) Studies on the constituents of Ailanthus integrifolia. Chem Pharm Bull (Tokyo) 42, 1669-1671.

40. Gasser JA \& Willnecker J (2012) Bone measurements by peripheral quantitative computed tomography in rodents. Methods Mol Biol 816, 477-498.

41. Zhang Y, Leung PC, Che CT, et al. (2008) Improvement of bone properties and enhancement of mineralization by ethanol extract of Fructus Ligustri Lucidi. Br J Nutr 99, 494-502.

42. Lau WS, Chan RY, Guo DA, et al. (2008) Ginsenoside Rg1 exerts estrogen-like activities via ligand-independent activation of ERalpha pathway. J Steroid Biochem Mol Biol 108, 64-71.

43. Xie Y-M, Xu Y-G, Zhao J-N, et al. (2004) Effect of osteopractic total flavone on density of bones of rats without ovaria and levels. China J Basic Med Tradit Chin Med 10, 34-37.

44. Zhang J, Li HP, Yang PL, et al. (2009) Effects of total flavonoids from rhizoma Drynariae medicated serum on proliferation, differentiation, cell cycle and apoptosis of osteoblasts in vitro. Zhong Yao Cai 32, 1090-1093.

45. Pang WYWX, Mok SK, Lai WP, et al. (2010) Naringin activates estrogen receptor ligand-independently in rat osteoblast-like (UMR 106) cells and improves bone properties in ovariectomized mice. Br J Pharmacol 159, 1693-1703.

46. Bord S, Ireland DC, Beavan SR, et al. (2003) The effects of estrogen on osteoprotegerin, RANKL, and estrogen receptor expression in human osteoblasts. Bone 32, 136-141.

47. Chen XW, Garner SC \& Anderson JJ (2002) Isoflavones regulate interleukin-6 and osteoprotegerin synthesis during osteoblast cell differentiation via an estrogen-receptordependent pathway. Biochem Biophys Res Commun 295, 417-422

48. Zhu H, Wang WJ \& Wang ZM (2010) Effects of Drynariae rhizoma total flavone on Smad1 Smad5 mRNA expression in osteoporosis. Chin Arch Trad Chin Med 28, 200-204. 